\section{O eu e seus afetos: um ensaio sobre o emissor e a ilusão identitária}

\section{RESUMO}

Este ensaio tem por objeto um efeito particular de qualquer ação observada, portanto, comunicada: a identificação do agente, emissor ou receptor. Propomos que um interlocutor participa da sua própria definição ao agir, não só quando 0 faz expressamente, visa esse fim e fala sobre si - objeto da primeira parte deste artigo -, mas também quando discorre sobre o mundo que contempla, atribuindo-lhe sentido e valor - objeto da segunda parte.

\section{ABSTRACT \\ This essay deals with the identification of the agent, source or receiver, in any communicational act. \\ PALAVRAS-CHAVE (KEY WORDS) \\ - Identificação (Identification) \\ - Emissor (Emitter) \\ - Receptor (Receiver)}

Clóvis de Barros Filho

Cásper Líbero - ESPM, ECA/USP

Felipe Lopes

Pesquisador em Filosofia da Comunicação - ESPM ...só hÁ AfETos. Só os desejos atualizam. Em tempo real, só potências. Incomunicáveis. Solidão. Representações e relatos sobre si estão sempre atrasados. Anúncios de um produto perecido de ofício. Comunicação do que não é mais. Depoimentos e perfis, tão ávidos pelo flagrante ao vivo e condenados a descrever cadáveres. Morbidez. Olhar travestido de um mutante para um eu que, passo a passo, vai-lhe fugindo ao viver. Ritmo de uma melodia eterna, sem refrão. Processo inesgotável do fracasso. Perseguição frustrante de um distanciamento progressivo. Mundo fugaz. Espelho da fugacidade do eu.

No princípio eram os estudos da emissão. Depois, os da recepção. Os primeiros colocam ênfase em efeitos comuns. Destacam que a mensagem da mídia afeta, indistintamente, quem a ela se expõe. Mas não só. Estabelecem um nexo de causalidade entre formas e conteúdos emitidos e correspondentes manifestações sociais.

As reflexões sobre a recepção, por sua vez, destacam efeitos singulares. Cada encontro com o mundo - exibido pela mídia - acarreta conseqüências particulares junto a este ou aquele observador, segundo suas especificidades. Assim, a grande descoberta do campo da comunicação, na segunda metade do século $X X$, denuncia, com estardalhaço, que o receptor não é passivo.

Há, implícito nessa diversidade de abordagens, um ponto comum: a comunicação precisa de alguém para comunicar, emitir e receber. Esse alguém, tomado por pressuposto, allant de soi, 
parece tão imprescindível para quem comunica quanto para quem se dispõe a teorizar sobre a comunicação.

Este ensaio tem por objeto um efeito particular de qualquer ação observada, portanto, comunicada: a identificação do agente, emissor ou receptor. Propomos que um interlocutor participa da sua própria definição ao agir, não só quando o faz expressamente, visa esse fim e fala sobre si - objeto da primeira parte deste artigo -, mas também quando discorre sobre o mundo que contempla, atribuindo-lhe sentido e valor - objeto da segunda parte.

\section{Identidade: discurso sobre o eu}

Estamos sempre nos apresentando. Mais ou menos explicitamente. Exigência dos encontros com o mundo. No momento em que conhecemos alguém, passamos a informar quem somos, quase sempre de forma dialogada. As perguntas que propiciam nossa apresentação são habituais, portanto, previsíveis. A situação Ihes confere uma forma, também previsível. Num bar, no preenchimento de uma ficha de emprego, num ônibus, etc.

Toda apresentação de si é um ritual. Obedece a uma seqüência definida, socializada no hábito. Qualquer transgressão é sancionada. Como iniciar uma conversa com um desconhecido num metrô cheio com a frase: "Sou uma pessoa generosa e por isso muitos abusam de mim".

Os passos que permitem a revelação de si são encadeados com rigor. A aparente espontaneidade dos atos nas interações decorre da ignorância das regras que presidem esses encontros. A situação pode fornecer os primeiros referenciais. Como num bar: "Você vem sempre aqui?" - a abordagem permite ao respondente apresentar um esclarecimento sobre práticas de lazer, habituais ou excepcionais.

A resposta oferecida, entre infinitas outras possíveis, começa a permitir a identificação do abordado, a reduzir sua contingência aos olhos de quem indagou. Determinada pelo afeto da abordagem, a resposta objetiva o interesse pela continuidade do encontro, autorizando-a ou não. Você trabalha com o quê? Duas perguntas de uma seqüência esperada. A inversão das mesmas suscitaria estranheza.

Assim, os interlocutores agem para se identificar segundo saberes práticos que, por serem incorporados, quase sempre dispensam ponderação. Obedecem, como numa orquestra, aos comandos da batuta de um maestro invisível. Antecipam soluções não calculadas, tendencialmente adequadas a condições objetivas de manifestação, como: idade presumida do interlocutor, sexo, indumentária, local do encontro etc.

Mas o que afinal apresentamos para esclarecer quem somos? A história que habitualmente contamos a nosso respeito e que, em geral, acreditamos ser definidora de nós mesmos, é excludente de todo o resto, de tudo o que não supomos ser. No entanto, também é pré-requisito da vida em sociedade. Interagir pressupõe identificar e identificar-se. Condição de inclusão, portanto. Discurso singular imprescindível, para nós e para os outros. Relato habitual que, por definir, discrimina $(A)$ e integra (B).

A) Identidade: relato definidor - de exclusão

Identidade é toda manifestação pela qual um indivíduo se atribui, prioritariamente por intermédio de um relato, um sentimento de continuidade e de relativa coerência. Manifestação que Ihe permite circunscreverse e estabelecer uma diferença específica, com pretensões de permanência, em relação ao que lhe é externo.

Objetiva-se numa

estrutura narrativa onde a consciência do eu é uma 
interpretação da própria trajetória que "encontra no relato, entre outros signos e símbolos, uma mediação privilegiada; esta última se serve da história tanto quanto da ficção, fazendo da história de uma vida uma estória ou, se preferirmos, uma ficção histórica entrecruzando o estilo historiográfico das biografias com o estilo romanesco das autobiografias imaginárias"1.

Identidade é memória e muito mais. Simples reconstrução narrativa da percepção dos fatos da própria trajetória? Não. A identidade é mais do que isto: à memória do que efetivamente percebemos como vivido vem juntar-se um apenas imaginado. A identidade, portanto, transcende a existência prática, factual.

"Mas as ciências humanas, nos ensinaram, (...), que esta singularidade era ilusória, que não havia nem substância nem substrato, mas um jogo múltiplo e indefinido de estruturas diversas, físicas, psíquicas, sociais, lingüísticas (...) que a alma não poderia ser, em hipótese alguma, o sujeito, ou a causa, ou a soma, mas no máximo o efeito. Ora, se o eu é vários outros, que resta do sujeito? Nada, sem dúvida, a não ser a ilusão de si. Como Narciso, ele é sujeito apenas de seu sonho"'.

Essa falta de um substrato exige de nós a repetição exaustiva do relato narrativo que nos define, para nós mesmos e para os outros. Relato das ilusões sobre si. Relato sem objeto. Vazio ontológico. Labirinto. Abismo. "O eu nada mais é do que essas qualidades que não são ele, como ponto de fuga para o qual convergem - de maneira ilusória - paralelas anônimas"3.

Ante a transformação - composto impermanente num oceano de impermanência - a identidade, para garantir minimamente a ilusão do eu, deve resistir, permanecer - ou pelo menos parecer permanecer - para si e para o outro. Algo na identidade deve permitir uma apresentação de si repetida, que se mantém ante qualquer nova condição objetiva de existência. Algo que habitualmente oferecemos ao mundo social como definidor de nós mesmos. Satisfação de uma exigência, também habitual, por parte de seus múltiplos universos: a apresentação de um ou mais traços distintivos.

Hábito percebido. Hábito interiorizado. Hábito socialmente aprendido. Habitus portanto. "Quanto a mim, escreve Hume, quando penetro mais intimamente no que chamo de mim-mesmo, esbarro sempre numa ou noutra percepção particular, calor ou frio, luz ou sombra, amor ou ódio, dor ou prazer. Não atinjo nunca a mim mesmo"4.

A crença no eu é primeira dentre as ilusões sociais. Condição de tantas outras. Condição da existência. Por isso, a mais incorporada. Inquestionável. Nem mesmo a consciência do seu caráter ilusório impede, nas múltiplas situações práticas da vida social, a sua pronta intervenção. Habitus identitário.

A ilusão do eu parece pressupor uma repetição possível, habitualmente garantidora, a qualquer interlocutor, da existência de alguém, de alguém que se chama $X$ ou $Y$, que é ou faz isto ou aquilo, que gosta disto ou daquilo, especialista nisto ou naquilo, que detesta este ou aquele ambiente, que se dá bem com este ou aquele tipo de pessoa etc. Desta forma, toda crise de identidade é uma crise de permanência ${ }^{5}$.

Percebemos a ilusão da permanência do eu - como ilusória - na medida em que somos constrangidos a flagrar, em algum aspecto do nosso relato identitário a diferença, a mudança. Erro? Nunca. Para Espinosa, "erro não é a ignorância pura e simples; é a ignorância da verdade completa que faz que tomemos por completa uma verdade mais ou menos completa"6. Um erro de representação, como o suposto erro de auto-definição, pressuporia a possibilidade 
de uma representação verdadeira. Um eu representável.

Mas só há afetos ${ }^{7}$. Só os desejos atualizam. Em tempo real, só potências. Incomunicáveis. Solidão. Representações e relatos sobre si estão sempre atrasados. Anúncios de um produto perecido de ofício. Comunicação do que não é mais. Depoimentos e perfis, tão ávidos pelo flagrante ao vivo e condenados a descrever cadáveres. Morbidez. Olhar travestido de um mutante para um eu que, passo a passo, vai-lhe fugindo ao viver. Ritmo de uma melodia eterna sem refrão. Processo inesgotável do fracasso ${ }^{8}$. Perseguição frustrante de um distanciamento progressivo ${ }^{9}$. Mundo fugaz. Espelho da fugacidade do $\mathrm{eu}^{10}$.

Se há erro, está na crença da possibilidade de uma única representação, de uma única identidade. Erra aquele que acredita afetar ao próximo como a si mesmo ${ }^{11}$. Ou pior: crê, por toda a vida, afetar-se identicamente; presume o eu de amanhã pelo de hoje. Erro escusável, se houvesse delito. O "bom pai de família" (bonus paterfamilia) se equivocaria em situação análoga. A existência social e suas exigências jurídicas induzem: falácia do nome, do RG, da digital. Só a foto, desatualizada, denuncia o perecimento.

Permanência: ilusão exigida, portanto. Impasse entre a alienação - de se crer sempre o mesmo - e a insanidade - de se crer outro a cada instante. Daí a tristeza: "é fácil ver que ela nasce da opinião (sobre si) e do erro que dela provém"12. Dentre as tristezas, a melancolia. Eliminação radical da alegria. Tristeza pelo corpo inteiro.

Uma nova representação de si exclui dolorosamente a anterior. Porta aberta para o suicídio: nossa imaginação nos reveste de uma contradição interna, tentativa alienada de auto-preservação, matar o novo para proteger a ilusão da permanência, eliminação de um invasor numa guerra identitária, um ato de legítima defesa. Desencontro dramático consigo mesmo (Deleuze).
Sem essa crença na permanência, também estariam comprometidas as relações. A fugacidade radical condenaria o interlocutor à incerteza, à absoluta ausência de referenciais. Falta de chão. A impossibilidade de prever tornaria vãs as expectativas. A redução aparente da contingência do outro, ilusória mas securitária, coloca sob os holofotes o mais habitual, garantindo, assim, aos que se relacionam alguma existência, como, por exemplo, enquanto um objeto de posse ${ }^{13}$ : meu marido, meu pai, minha professora, meu amor etc ${ }^{14}$.

Meditação pascaliana, por falar em amor: "O que é o eu? Alguém que ama alguém por causa de sua beleza amao mesmo? Não porque a varicela, que matará a beleza sem matar a pessoa fará que ele não a ame mais. $E$ se alguém me ama por meu discernimento, por minha memória ama mesmo a mim? Não porque posso perder essas qualidades sem me perder. Onde está pois este eu, se não está nem no corpo nem na alma? E como amar o corpo ou a alma a não ser por essas qualidades que não são o que faz o eu pois são perecíveis? Pois amaria alguém a substância da alma de uma pessoa abstratamente, quaisquer que fossem as qualidades que nela houvesse? Isso não é possível e seria injusto. Portanto, nunca se ama ninguém mas apenas qualidades"15.

A narrativa identitária, como todo discurso, encontra-se em circulação. Produção incessante de redefinição. A fala de quem pretende se definir - o eu falando sobre si mesmo - é apenas um momento dessa trajetória. A identidade é o resultado sempre provisório de um diálogo entre o social e o sujeito, entre as múltiplas representações enunciadas sobre esse último - e por ele flagradas - e a forma, sempre criativa e singular, pela qual as rearticula ${ }^{16}$. Por isso, a despeito da componente inventiva que caracteriza toda construção identitária, não há motivo para reduzi-la a uma pura ilusão biográfica ${ }^{17}$. Interação: condição de existência, condição 
da sua definição ${ }^{18}$.

Máscaras que se sobrepõem ${ }^{19}$. As novas adequam-se à topografia das anteriores, do já vivido. A personagem substituída dá as condições de possibilidade existencial daquela que lhe substitui. No teatro da existência social, não substituímos máscaras, criando indefinida e livremente novas personagens para novas relações. A definição identitária tem condições objetivas de natureza social.

É na pluralidade de manifestações sobre si que se encontra matéria prima para compor um quadro de características com mais chances de reconhecimento ${ }^{20}$. Manifestações muitas vezes contraditórias e que produzem efeitos sobre seu objeto ${ }^{21}$.

Nessa polifonia, os discursos identitários não se equivalem. Agem desigualmente na construção das representações que têm o sujeito como objeto. A medida dessa desigualdade não se encontra na sintática ou léxico mas na legitimidade de quem fala, na autoridade de que está investido o portavoz para se manifestar sobre esta ou aquela identidade ${ }^{22}$. A título de exemplo, participa da construção identitária qualquer manifestação de enaltecimento, de valorização social. Ora, esse tipo de manifestação será tanto mais eficaz quanto mais distante socialmente estiver o portavoz do sujeito enaltecido.

Em suma, o mundo social fornece elementos para uma auto-definição provisória ${ }^{23}$. Ao mesmo tempo, condiciona qualquer tipo de existência nele à indicação de características discriminantes, que facultem identificação. Sem relato identitário não há pertencimento.

B) Identidade: relato de pertencimento - inclu são

A identidade deve permitir a definição de traços distintivos e, ao mesmo tempo, inscrever seu sujeito/objeto numa representação coletiva. Por isso, dispor e poder oferecer uma identidade faculta o pertencimento a múltiplos grupos de naturezas diversas. A adequação da própria identidade com a do grupo exige permanente negociação. Perder para poder ganhar.

As memórias de família ${ }^{24}$ são um ótimo exemplo da invenção permanente e barganhada que revela os traços distintivos desta ou daquela estirpe ou linhagem. Os ritos de instituição familiar constituem uma entidade apresentando-a como estável, constante e imune às oscilações dos afetos de seus membros. Esses ritos enquadram relações, conferindo-lhes uma singularidade, uma socialização particular da libido: a produção e reprodução de afetos obrigatórios inerentes a este pertencimento institucional - amor entre irmãos, filial, conjugal, materno etc ${ }^{25}$.

As heranças fenotípicas, porque reveladoras da ascendência mais propensa a eternizar sua singularidade, são objeto de intensa disputa social. Puxar do pai ou da mãe cores ou proporções de extensão é muito mais do que um determinismo cromossômico ${ }^{26}$, mais do que reproduzir um existir comum familiar; é atualizar as origens, fazer crer na perenidade, lutar por um passado comum. Eis o dever da memória identitária: piedade e gratidão pelo passado compartilhado, já que este, como observa Jankélévitch, "não se defende sozinho, como o presente e o futuro..."27.

Essa construção de uma singularidade coletiva, supostamente garantida pelo parentesco, é apenas um tipo de identidade de grupo institucionalizado. O pertencimento a esses grupos pressupõe sempre algum cálculo sobre suas condições, custos e eventuais benefícios, isto é, afetos positivos que só as relações próprias àquele universo podem proporcionar. Assim, o denominado individualismo, supostamente característico das sociedades contemporâneas e marcado por baixos níveis de adesão institucional28, decorre da dificuldade, por parte de alguns grupos sociais, de continuar oferecendo 
remunerações simbólicas compensatórias das perdas de traços identitários individuais inerentes a qualquer pertencimento ${ }^{29}$.

Inversamente, grupos mais fechados, com fronteiras simbólicas nítidas, objetivadas em altos custos de entrada e defecção, pretendem controlar absolutamente os mecanismos de definição identitária. Intolerância: coerência aparente do coletivo em detrimento da diversidade individual. Assim, a identidade, permanentemente reconstruída, é condição de ingresso, permanência e até de exclusão em qualquer espaço social.

Um espaço social é um conjunto organizado, um sistema de posições sociais que se definem umas em relação às outras. Pais e filhos, chefes e subordinados, grandes vedetes e obscuros fracassados. Não há vencedores sem vencidos, ricos sem pobres etc. $O$ valor dessas posições só pode ser avaliado pela distância que mantém com outras, inferiores ou superiores $^{30}$.

Não é possível, portanto, definir uma posição pela simples análise de suas características intrínsecas. O sentido e o valor das mesmas dependerão do quanto elas se distinguem das demais posições. Em outras palavras, um espaço social é um sistema de diferenças que define suas posições naquilo que elas excluem outras. A identificação da posição do outro é, portanto, condição da identificação da própria.

Mas, como identificar o outro? Como ter certeza da sua existência? A certeza do cogito, de poder duvidar, esta nunca a teremos a não ser para nós mesmos. $O$ cogito autoriza o flagrante da existência, mas só na primeira pessoa. Para as outras...não somos o seu espírito. Quem poderia garantir que qualquer outro cogita como eu. Esse outro? Certamente não. Poderia tratar-se de uma engenhoca programada para nos enganar. Mas, se a certeza do cogito nos escapa, por que não, para garantir o outro, uma certeza de segunda classe? Menos imediata?
O outro por analogia. Solução também cartesiana ${ }^{31}$ : nenhum robô poderia se adaptar à liberdade de um diálogo cujos encadeamentos podem ser pouco previsíveis. O outro deve existir porque se comunica comigo, porque dialoga. Se consegue me acompanhar quando mudo de assunto é porque me segue, infere como eu. Existe, portanto, como eu. O outro a partir do eu. É no diálogo, portanto, na relação que se objetiva o encontro de consciências, que se cria uma generalidade perceptiva.

Analogia pelo diálogo, analogia pelo corpo. Para Husserl ${ }^{32}$, o reconhecimento do outro, sua identificação, só é possível a partir da experiência de meu corpo vivo, como fonte de movimentos, de sensações e de sentimentos. O que eu percebo do outro é, antes de tudo, um outro corpo em ação, expressivo. É porque eu identifico imediatamente uma semelhança entre meu corpo e o do outro que se opera uma transferência de sentido: eu vivo como corpo; vejo um outro corpo como o meu; este outro corpo deve ser habitado por um outro eu. Como na analogia cartesiana, o outro surge a partir do eu. Num determinado espaço. Um espaço de intersubjetividade.

Intersubjetividade: pertencimento de qualquer sujeito à generalidade do mundo. Perceber o outro enquanto sujeito universal pressupõe admitir, como quer MerleauPonty, que "eu sou dado a mim mesmo, isto é, que eu me encontro engajado num mundo físico e social"33. Para compreender qualquer tomada de posição subjetiva é preciso voltar-se para o espaço social onde a formação deste sujeito enquanto corpo falante se efetua numa configuração socialmente constituída ${ }^{34}$.

Desta forma, se as posições de dominante e dominado só podem ser definidas em relação e em função da outra, o reconhecimento do dominante por ele mesmo - enquanto dominante - depende da existência e da identificação de um outro, de um dominado. Analogamente, 
o reconhecimento do dominado por ele mesmo - enquanto dominado - está na existência e na identificação de posições de dominação que ele (ainda) não ocupa. Um se identifica pelo outro.

O agir do dominado objetiva o reconhecimento da posição de dominação. Permite não só a existência do dominante, como sua identificação por ele mesmo. O pressuposto para a consciência da própria posição é a capacidade de se colocar numa posição exterior a si mesmo, transcenderse. Identificar seus traços distintivos a partir da perspectiva do outro simbolicamente representado.

Mais do que da simples existência de uma outra posição, ou de seu ocupante, o dominante depende, para se reconhecer como tal, do reconhecimento da sua existência como dominante pelo dominado. Esse reconhecimento se dá por um conjunto de ações próprias às posições sociais dominadas no campo.

Essas ações, por sua vez, são, em grande medida, não pensadas, decorrentes de um saber prático interiorizado, de um habitus. Assim, o dominante só se vê como tal em função de um comportamento habitual do dominado que reconhece a dominação. É o habitus do dominado, objetivado em ações socialmente regradas, que permite ao ocupante de uma posição de dominação identificar a distância social que o separa do primeiro. Se cada dominado agisse de forma socialmente caótica ante o dominante, a dominação estaria comprometida pela impossibilidade de auto-identificação deste último.

Mas a posição social que nos serve de referencial carece de objetivação permanente. Assim, só as tomadas de posição, isto é, as manifestações dos múltiplos agentes de um universo, indicam, tornam visíveis, aos observadores as distâncias que os afastam. FacultamIhes o flagrante da estrutura do espaço. Se essa estrutura do mundo social se subjetiva no habitus de seus agentes é porque os afeta através de manifestações que implicitamente revelam as distâncias entre suas posições, suas regras e seus troféus ${ }^{35}$.

As idéias dos afetos do corpo em socialização - resultado da atividade do agente social, observador de outras posições e ações estruturantes do campo visíveis através das manifestações de seus ocupantes - têm por objeto, além da natureza do próprio corpo, a natureza daqueles corpos exteriores que o afetam, ou seja, dos agentes sociais com quem se relaciona e cuja ação observa.

As idéias dos afetos do corpo não permitem o conhecimento adequado dos corpos exteriores. Elas nos permitem percebê-los apenas muito parcialmente, na medida em que agem sobre nós por este ou aquele de seus movimentos. A idéia completa de um objeto situado fora de nós - como os demais membros de um campo a que pertencemos - não está, de forma nenhuma, em nosso espírito. Por isso, embora membros de um mesmo campo, seus agentes não se submetem a socializações idênticas. Já que este afeta seus membros singularmente, na medida dos encontros e flagrantes singulares.

As distâncias sociais entre os membros do campo, autorizantes ou não desta ou daquela tomada de posição, são percebidas pelos seus agentes na medida em que os afetam, isto é, transformam o observador, adequando-o às expectativas de seu comportamento. Se as posições sociais se convertem em disposições de ação é porque as primeiras, visíveis em função das manifestações daqueles que as ocupam, condicionam encontros e relações mais ou menos felizes ao longo de uma trajetória no campo.

Assim, os afetos, interpretações psíquicas das ininterruptas modificações corporais que o mundo social nos impinge, oscilam em função dos encontros, também ininterruptos, com esse mundo ao longo de uma trajetória ${ }^{36}$. Encontros felizes são os que aumentam a potência de agir. Isto se dá quando há uma adequação, sempre 
tendencial, entre posições objetivas no espaço social e disposições subjetivas de ação. Em outros termos, quando inclinações dos agentes sociais coincidem com ações autorizadas, esperadas ou exigidas dos ocupantes de suas posições ${ }^{37}$.

O mundo que nos afeta é só o mundo percebido. Desdizendo Berkeley ${ }^{38}$, há entre o mundo social perceptível - que poderia ser flagrado num instante - e o mundo social efetivamente percebido abrupta redução. Só este último afeta o ser percipiente e, assim, o socializa. Exemplo: os artigos científicos são produções acadêmicas, tomadas de posição próprias a esse campo. Por mais que estejamos a par da produção em questão, sempre nos deixamos afetar por este ou aquele autor, paradigma ou corrente de pensamento em detrimento de outros que nos escapam. Nossa socialização, propriamente acadêmica, fica, portanto, determinada por essa trajetória singular e seletiva de encontros com as manifestações dos membros do campo.

O mundo encontrado produz efeito. Transforma. Os afetos, como os desejos ${ }^{39}$, interpretam a transformação. Estão em fluxo. Desejos sobrepostos. As coisas no mundo valem na medida em que os satisfazem. Valores sobrepostos. Mudamse os desejos, mudam-se os valores. $O$ mundo nos afeta, nos oferece o desejado e, por isso, passa a ter valor. Um valor singular, como é singular nossa trajetória nele.

Já a identidade, como vimos, supõe a permanência. Ou melhor: a ilusão coletiva da permanência. $O$ valor singular dos afetos denuncia perigosamente o trânsito. Uma definição estável do eu requer valores que não evaporem a cada nova experiência. Princípios. Estes estão desde o início da trajetória. Imunes às oscilações do mundo contingente e seus afetos. Berço. Tudo é uma questão de berço quando se quer ser o mesmo do começo ao fim.
Identidade: discurso sobre o mundo e seu valor

A identidade é inseparável do valor. A identificação do eu se confunde com a identificação do mundo. A existência discriminada do indivíduo é condição e efeito da reflexão axiológica, isto é, da atribuição de valor. Esta, por sua vez, participa, com outras ações, da construção da representação daquele agente particular. Em outras palavras, ação e atribuição de valor afirmam, atualizam e impõem uma individualidade. Como observa Polin, "toda avaliação implica uma avaliação de si mesmo"40. Porque o mundo é um espelho.

Mas, onde está, afinal, o valor das coisas. Nelas mesmas? Se a resposta for afirmativa, cabe uma segunda pergunta: em todos os seus átomos? E uma terceira: no núcleo ou na eletrosfera? Talvez os óculos de Platão nos ajudem a encontrar o valor imanente à coisa, o justo na própria ação, o belo lá mesmo na paisagem contemplada etc. Só noutro mundo, não atômico, podem residir tantos absolutos intangíveis.

Se não está nas coisas do mundo, onde está? Se nada importa em si - porque não há valores imanentes ao mundo - de onde vem a importância? Quando nos ensinam que os deveres cívicos - como votar - são fundamentais, a que estão se referindo? Se nada vale em si, pode não haver barbárie no estupro de uma criança de colo?

Se o valor está aqui, no mundo percebido, e não está na coisa, só pode ser prerrogativa de quem a contempla. Só tem valor o objeto quando convertido em mensagem, quando flagrado. E nos limites do flagrante. Fenômeno. Se o valor é atribuído por um sujeito que observa, o mundo não percebido é indiferente. Não vale. Equivale a todo o resto também não percebido. A percepção é, portanto, condição do valor. Sua atribuição depende de contemplação do mundo, recepção e emissão. De comunicação, em suma. Por 
isso, todo valor é comunicado. Por isso, toda ética - ação de atribuir valor - é na comunicação. E ética na comunicação, simples pleonasmo ${ }^{41}$.

Mas o sujeito, para valorar, atribuir importância, precisa de critério. Afinal, com base em que referencial pode-se afirmar que para este indivíduo uma coisa vale mais do que outra? Qual o gabarito para a contemplação do mundo? Quantos pontos precisa o real para ser relevante? Qual a relação candidato $x$ vaga para a virtude? Qual a nota de corte da felicidade?

Desejo. Só o desejo. Importa tudo que desejamos. O desejo é a medida do valor do mundo. Na sua ausência, nada importa. Tudo indifere, se equivale. $O$ valor advém dos afetos. Mas então, o que vale? Todo real flagrado, transformado em mensagem, que aumenta a potência de quem observa. É bom, portanto, tudo o que desejamos. Não o contrário. Nunca desejamos nada por ser bom. Nem poderíamos. O desejo é primeiro em relação ao valor, em relação a tudo. Nada vale antes dele. Tudo vale em função dele. Só para quem deseja.

Mas se cada um atribuísse sentido e valor às coisas em função de sua própria potência de agir - desejo - não haveria entendimento possível e comunicação entre as pessoas. Só a existência de algum sentido comum garante um mínimo de ordem e comunicabilidade. Uma sentença para cada cabeça? Seria muito pouco convivial para ser honesto. "Na falta de uma verdade objetiva, só escapamos à pura e trágica dispersão dos pontos de vista singulares pela lei do grupo (as 'tribos') ou da maioria (a democracia)"42.

No grupo, a definição do que deve ser socialmente aceito como desejável e valioso é objeto de luta. A imposição de um valor, entre muitos outros possíveis, será legítima quando inquestionável em seu procedimento. Desta forma, qualquer valor tenderá à aceitação quanto menos parecer corresponder, arbitrariamente, ao que é, ao desejo, à natureza ou conatus deste ou daquele agente. Nessa luta, propriamente social, pela definição legítima do sentido e valor das coisas (A), exclusões e concordâncias coabitam (B).

\section{A) Valor como objeto de luta social}

$\mathrm{Na}$ impossibilidade, por parte de um agente social, de impor a todos o valor $\mathrm{e}$ o sentido ${ }^{43}$ que mais lhe convém servindose de um argumento subjetivo - como o de considerar uma coisa de alto valor apenas por aumentar sua própria potência de agir aquele agente faz prevalecer seu interesse fazendo crer que o valor é imanente a esta coisa - como um clássico da literatura - e, portanto, independente de qualquer avaliador.

Dominação e alienação, portanto, dependem do êxito desse empreendimento. A crença no valor imanente das coisas faz ignorar o caráter arbitrário do processo de sua atribuição, a não reconhecer "o poderio externo que nos domina, a forma como passamos a desejá-lo, a identificar-nos com ele"44. Ignora-se, em suma, o caráter social da construção do desejado.

Assim, por não nos reconhecermos como causa do desejo, acreditamos agir em vista de fins, em função de causas finais ${ }^{45}$. Por acreditarmos que o sentido e o valor das coisas estão nelas mesmas, fora e independentes de nós, tornamo-nos finalistas e normativos. A crença que coisas, ou acontecimentos, são importantes em si, nos faz esquecer que o desejo é a instância última de definição do que importa ${ }^{46}$. Por não percebermos que as coisas apenas são, indiferentes, sem importância, e que importam apenas para nós, que sentido e valor são prerrogativas de atribuição de um sujeito, que nos submetemos a valores préestabelecidos, a sentidos já outorgados.

Desta forma, o homem que, segundo a conhecida fórmula de Protágoras, seria a medida de todas as coisas não é nem o indivíduo nem a espécie mas "um grupo social cujos membros sustentam a existência dos mesmos valores e que 
estruturam esta avaliação comum das coisas"47. A medida das coisas continua, portanto, no homem, enquanto processo ininterrupto de subjetivação de estruturas sociais. Assim, a luta social por excelência é pela definição e imposição do sentido e valor das coisas do mundo, de uma classificação legítima dessas coisas.

Resultado de uma tomada de posição, determinada histórica e socialmente e objetivada numa formulação discursiva, todo valor pressupõe uma atribuição manifesta a partir de uma posição no mundo social, a partir de um ponto de vista excludente de infinitos outros. Assim, desejos, conatus ou clinamens se equivalem de direito - afinal são todos iguais perante a lei - mas não de fato, enquanto manifestações diversamente autorizadas pelo grupo.

Com efeito, cada manifestação que interpreta o mundo atribuindo-lhe subjetivamente sentido e valor apresenta eficácia singular na construção do sentido e valor social das coisas. Isto porque qualquer manifestação é sempre enunciada por um porta-voz a partir de uma posição social singular. Seus ocupantes estão desigualmente autorizados a interpretar o mundo.

O sucesso de uma manifestação que, movida pelo interesse social - desejo - de quem fala, atribui sentido sobre o que fala depende da felicidade do encontro do que é falado com quem ouve. A felicidade desse encontro é, em grande medida, definida antes da manifestação, portanto antecipada. Afinal, os ocupantes desta ou daquela posição social já estão socialmente legitimados a falar e a ouvir.

A concordância feliz por parte de quem ouve, a certeza de que "era isso que precisava ser dito naquele momento", a potência de agir aumentada pelo ajuste entre as palavras ouvidas e a expectativa que as precedia resultam apenas de uma adequação - não no sentido espinozano - entre um habitus lingüístico e um espaço social de definição de valor e sentido sobre as coisas ditas.

Em outras palavras, o discurso sobre o sentido e valor das coisas do mundo terá sua eficácia condicionada ao seu próprio valor social. A competência técnica, portanto social, de quem fala sobre este ou aquele recorte da realidade será avaliada, valorada em um mercado de enunciações, isto é, em função de um sistema social de formação de um preço lingüístico em grande medida já interiorizado pelo receptor. Neste mercado, como em qualquer outro, há, em meio à intensa competição, inúmeras concordâncias sobre suas regras, seus limites e participantes.

\section{B) Valor: exclusões e concordâncias}

Toda trajetória é constituída por múltiplos encontros com o mundo social percorrido. Esses encontros se objetivam em relações que transformam seus agentes, produzem efeito sobre eles. São afetos passionais porque desencadeados por elementos que Ihes são externos. Nunca somos, portanto, a causa - adequada - de nossas paixões ${ }^{48}$.

As relações com outros agentes deste mundo social são governadas pelas leis naturais da identificação: assim, o homem, sendo parte da natureza, é afetado, de múltiplas maneiras, por outras partes dessa mesma natureza. Trata-se de um ser natural porque obedece à necessidade imanente das leis do Todo-Uno.

Mas, dado que o homem se encontra, desde o início de sua trajetória, engajado nesse comércio afetivo, sua existência é também social. Vive em espaços de relações sociais que o afetam e o constituem. Assim, "o estado social é uma continuidade do estado natural; em outras palavras, o homem se socializa segundo uma necessidade que não escapa à ordem natural, e esta socialização dinâmica é, antes de tudo, afetiva" 49 .

Todo campo social é um espaço relativamente autônomo de relações. Essa autonomia relativa se deve à especificidade, 
também relativa, das relações sociais que o constituem e de seus afetos. Os agentes do campo, nessas relações, ao se deixarem afetar, submetem-se a um processo próprio de socialização ${ }^{50}$. Logo, a despeito da luta social pelo acesso aos troféus, que caracteriza qualquer campo, há algo em comum entre seus integrantes. Algo sobre o qual a concordância é fundamental.

Sem uma certa homogeneidade entre causa e efeito, nenhuma relação causal é possível. Dois seres que não tivessem nada em comum evoluiriam em planos distintos sem poder se afetar"1. "Portanto, a nossa potência de agir, de qualquer modo que ela seja concebida, pode ser determinada, e, conseqüentemente, favorecida ou entravada pela potência de uma outra coisa singular, que tem algo em comum conosco, e não pela potência de uma coisa, cuja natureza seja inteiramente diferente da nossa"52.

Por isso, seres semelhantes tendem a se afetar mais ${ }^{53}$. Não pode haver inveja da altura de uma girafa. Da mesma forma, as ações inscritas nas relações entre agentes submetidos a socializações semelhantes também tendem a afetar mais ${ }^{54}$. Assim, o pertencimento a um campo intensifica os afetos por assegurar o domínio de um sentido comum a qualquer manifestação. Comunidade de interesses convertida em comunidade semiótica. A pilhéria de um panificador ante um psicanalista é menos ofensiva do que a apresentada entre colegas.

Socializações semelhantes não são prerrogativa exclusiva dos membros de um determinado campo. Antes de pertencer a um deles, todos os indivíduos já se encontravam inscritos num "campo dos campos", um campo das classes sociais. Todo agente social, desde o início de sua trajetória, ocupa posições na estrutura de classe. Seria impensável cogitar em investimentos sociais em qualquer campo sem considerar o pertencimento a uma delas ${ }^{55}$.

Em outras palavras: as práticas dos agentes membros deste ou daquele campo são o produto da composição de processos de socialização intrínsecos ao campo e extrínsecos a ele. Por isso, ocupantes de posições semelhantes em dois ou mais campos tendem a adotar, por homologia, estratégias semelhantes, de conservação ou de subversão da estrutura do espaço, dependendo da posição que ocupam.

Relacionam-se e afetam-se privilegiadamente. Porque, apesar de disputarem troféus diferentes, segundo regras também distintas, pertenceram ou ainda pertencem às mesmas instâncias de socialização. Num colégio de elite estão sendo preparados, lado a lado, dominantes para distintos espaços sociais. Da mesma forma, coincidem a modalidade e o local de práticas esportivas, atividades culturais, etc.

A adesão ao valor dos troféus, às regras do jogo, ao limite do eticamente aceitável das tomadas de posição são concordâncias que pressupõem o pertencimento a qualquer campo social. Toda estratégia de subversão esbarra nesse implícito social, que não deve ser confundido com os tão preconizados pactos ou consensos sociais.

Como observa Mary ${ }^{56}$, todo consenso se refere a um fundo comum de representações "consideradas no seu conteúdo e não nas suas formas a priori, que as tornam possíveis e pensáveis". O habitus, diferentemente, é um sistema de esquemas que define o sentido dos limites da ação no interior de uma formação social. Encontra-se, portanto, no princípio da inteligibilidade das práticas simbólicas e ideológicas. Não requer um engajamento calculado, uma manifestação explícita de adesão.

O encontro de duas pessoas ou coisas é o encontro de dois conatus ${ }^{57}$. Vimos que a semelhança é condição do afeto. Duas pessoas podem se afetar na medida em que apresentam características comuns. Assim, no campo, o que permite o afeto entre seus membros são suas 
condições de existência tacitamente aceitas por todos. Mas o campo, como todo espaço social estruturado, também se objetiva numa arena de conflito: interesses comuns cuja satisfação é excludente. Essa exclusão implica afetos negativos.

Mas o que, na semelhança parcial de membros singulares de um mesmo campo, poderia ensejar um afeto negativo? Imaginemos dois integrantes $\mathrm{X}$ e $\mathrm{Y}$ de um campo qualquer. $X$ possui as características $\mathrm{A}$ e $\mathrm{B}$ e $\mathrm{Y}$, as características $\mathrm{A}$ e $\mathrm{C}$. Imaginemos que A seja o reconhecimento comum do grande valor que representa ocupar determinado posto. Em que medida, neste caso, $\mathrm{O}$ indivíduo $\mathrm{X}$ pode ser danoso ao indivíduo $Y$ ? Em que medida o conatus de $X$ pode diminuir o de $Y$ ? A causa desta diminuição não pode ser $A$, já que um ser de natureza A não poderia, ao agir, desencadear conseqüências que neguem essa mesma natureza. Neste caso, $\mathrm{X}$ e $\mathrm{Y}$ nunca poderiam ter existido.

$E$ a propriedade $A$ de $X$ não poderia trazer dano à $C$ de $Y$ ? Também não. Se as conseqüências da ação de alguém de natureza $A$ acarretassem a negação de $C$, haveria incompatibilidade em $Y$ destas duas características, posto que $Y$ é simultaneamente $A$ e $C$. $Y$ seria ontologicamente impossível. E a propriedade $B$ de $X$ poderia causar dano à propriedade $A$ de $Y$ ? Não, pela mesma razão da combinação anterior. $A$ incompatibilidade entre $A$ e $B$ tornaria $X$ inviável.

Logo, nunca é pela nossa natureza comum que poderemos afetar negativamente $O$ outro. São as propriedades $B$ de $X$ e $C$ de $Y$ que podem produzir dano reciprocamente. Assim, num determinado campo social, a luta que exclui e afeta negativamente não pode ter como causa o que é comum.

O campo, enquanto espaço de afetos decorrentes de encontros sociais relativamente específicos, é um universo passional. Na paixão, os agentes sociais em relação são exteriores uns aos outros.
Assim, a lógica de funcionamento de qualquer campo, objetivada na dupla tendência de concordâncias e disputas, só pode encontrar fundamento na paixão.

Detalhando a proposta: no amor reconhecemos o outro como fonte de nossa existência. Nosso conatus é determinado pelo do ser amado. Portanto, queremos que este último se fortaleça. Para isso, desejamos que o outro ame o que amamos. Se odiar, odiará a fonte de nossa existência e, por conseguinte, a nós. O ódio, o desprezo ou mesmo o desinteresse do outro pelo ser amado reduz o conatus deste último e, conseqüentemente, o nosso. Por isso, odiamos a todos que odeiam o que amamos. É o que sentimos por aqueles que, por não pertencerem ao mesmo universo social, não jogam o mesmo jogo e, portanto, não atribuem valor a seus troféus. Desprezam o que amamos.

Mas também entramos em conflito com os que amam o que amamos. Isto porque o amor apaixonado tende à posse. Sendo fonte de nossa existência, queremos a segurança de tê-lo sempre junto a nós. Desta forma, se o outro ama o mesmo ser, pressupomos que também buscará possuílo, o que pode afastar-nos do objeto amado. Esses são os afetos que caracterizam a praxis de membros em luta num mesmo campo.

Não é porque amamos a mesma coisa, ou disputamos o mesmo troféu, que entramos em conflito. Como vimos, este último nunca pode decorrer de propriedades comuns. Somos potência desejante e o amor só faz confirmar nossa natureza. Mas, então, de onde vem o conflito?

Lutamos porque imaginamos diversamente o ser amado, o objeto da luta. Amamos imaginando estar de posse dele, já detê-lo. Odiamos, inversamente, a idéia deste objeto possuído por outro. $\mathrm{O}$ ser amado permanece o mesmo para os dois. Mas a imaginação de seus amantes o discrimina em suas mentes.

O pertencimento a um campo, como o 
ciúme, implica múltiplos afetos decorrentes da singularidade das representações que constrói cada agente sobre os bens em circulação e em disputa: amor pelo troféu, ao que atribuímos em disputa um valor positivo, como o posto de Governador ou Presidente da República para o agente do campo político, a direção de um prestigioso centro de pesquisa científica para o campo acadêmico, a seleção brasileira, para o jogador de futebol; amor por aquele que joga o jogo, que ama e reconhece o mesmo troféu, isto é, atribui valor positivo ao que amamos. Indica este afeto a declaração: "somos adversários circunstanciais, mas tenho profundo respeito pelo candidato Cintra"58; ódio pelos co-participes do campo, porque disputam conosco os troféus. Afeto presente nas lamúrias de derrotados sobre suposta imparcialidade das bancas de concursos universitários; amor por nós mesmos, pois, ao amarmos quem reconhece o troféu que desejamos, reconhecemo-nos como causa do aumento do conatus do campo de que participamos. Assim, ao reconhecer a relevância da atuação do nobre adversário, "ilustre causídico", contribuímos para aumentar o valor, a importância do campo jurídico; ódio por nós mesmos, pois, ao odiarmos quem ama e reconhece o troféu que desejamos, reconhecemo-nos como causa do apequenamento do conatus do campo de que participamos: "Às vezes dá vergonha de ser jornalista esportivo"59; ódio pelo troféu, pois, dada a concorrência, concebemo-lo como podendo ser possuído por outro: "que fique ele com isso; conseguiremos coisa muito melhor"60.

Assim, a dupla tendência de acordo e conflito entre membros integrantes de espaços sociais estruturados e relativamente autônomos encontra na filosofia de Espinosa sólido ponto de apoio. Afinal, amaremos outro por amar o que amamos e o odiaremos por pressupormos querer afastá-lo de nós.

Nesses espaços, socializações semelhantes produzem razões práticas semelhantes, tendências de agir e de reagir semelhantes, ante encontros com este ou aquele elemento do mundo, ante esta ou aquela condição material de existência. Os encontros com o mundo, porque são alegres ou tristes, porque aumentam ou diminuem nosso conatus, nos ensinam a agir de forma a conservar-nos.

Nesse processo pedagógico, experimentamos a alegria e a tristeza repetidamente e associamos tais afetos a este ou aquele elemento do mundo social que consideramos causa61. Desta forma, ao nos depararmos com um elemento $A$ ele nos remeterá a $B$ se tivermos sido afetados associadamente por $\mathrm{A}_{\text {e }} \mathrm{B}^{62}$.

O habitus é, portanto, conseqüência da sobreposição de afetos passionais. Toda socialização, e o habitus é parte não refletida desta, implica paixão, isto é, influência do mundo social sobre o ser, em afeto inadequado. A paixão constitui o ser a partir de seus encontros com outro seres no mundo. Daí a sua passividade, a sua impotência. O nosso êxito na vida social, o sucesso do esforço que empreendemos para preservar nosso ser, depende, no caso da paixão, do estado de preservação de si - conatus - do ser desejado. O apaixonado é sempre determinado pelo outro.

Por isso, o fato de pertencermos a um espaço de relações relativamente autônomo, como os campos político, universitário, literário, etc. implica sempre investimentos determinados por afetos passionais. Se as ações no campo só são explicáveis a partir das ações de seus outros agentes é devido à heteronomia - incapacidade não percebida de autodeterminação - de todos seus participantes. A existência no campo, objetivada por esta ou aquela tomada de posição, só se entende a partir da alteridade, da existência social do outro, da posição por ele ocupada.

Concluímos, portanto, com a unidade ontológica entre o campo, enquanto espaço de posições objetivas e o habitus enquanto disposições subjetivas de agir ${ }^{63}$, de pensar 
e de se definir. A idéia de um afeto qualquer não nos fornece o segredo da sua origem: tomada nela mesma ela não contem nada que nos permita discernir entre o que ela deve ao agente social afetado e o que ela deve ao meio, ao campo, enquanto espaço de relações e afetos. Não há, portanto, como discriminar o universo social objetivamente considerado da subjetivação de alguns de seus aspectos flagrados ao longo da trajetória de qualquer um de seus agentes $^{64}$.

Por isso, o discurso identitário, enquanto ação comunicada - enunciada/ recebida - e identificadora de alguém é indissociável dos processos de socialização de que é objetivador. Assim, o eu pode ser melhor compreendido como obra coletiva de manifestações estruturantes e estruturadas pelo espaço social e discursivo no qual circula, com resultado sempre provisório, e da qual participa, de forma mais refratada do que refletida seu sujeito/objeto .

\section{Notas}

1 Ricoeur, P. Soi-même comme un autre. Paris, Seuil, 1990. p. 138.

2 Comte-Sponville, A. Mythe d'Icare. Paris, PUF, 1988. p. 38.

3 Idem, p. 46.

4 Hume, D. Traité de la nature humaine. Paris, PUF, 1968, p. 343.

5 "O fundamento de meu ser e de minha identidade é puramente moral: ele está na fidelidade à fé que jurei a mim mesmo. Não sou realmente o mesmo de ontem; sou o mesmo unicamente porque me confesso o mesmo, porque assumo um certo passado como sendo meu, e porque pretendo, no futuro, reconhecer meu compromisso presente como sempre meu". Conche, M. Montaigne et la philosophie, Paris, ed. de Mégare, 1987, pp. 118 - 119.

6 Espinosa, B. Ética. São Paulo, Abril Cultural, 1979 . (Col.
Os Pensadores), Proposição XVIII, escólio, e Proposição XXV.

7 Sobre os afetos, ver Gueroult Martial, Spinoza, Tome 2, L'Ame (Ethique 2), Paris, Aubier-Montaigne, 1997.

8 Kaufmann J-C. destaca a eternidade e 0 fracasso: "A identidade é justamente o resultado deste esforço infrutifero, mas incessante do indivíduo para fabricar sua unidade (grifo nosso)". Ego. Paris, Nathan, 2001, p. 262.

9 A estabilidade identitária aparece como uma crença mais ou menos vã, dado que o indivíduo encontra ou flagra, ao longo de sua trajetória, um real estilhaçado e constitutivo da sua verdadeira infra-estrutura. Sobre este tema, ler Martuccelli, D. Grammaires de l'individu. Paris, Gallimard, 2002.

10 Strauss A. Miroirs et masques. Paris, Métailié, 1992.

11 Pelo mesmo principio cremos que tudo o que nos afeta, afeta a todos da mesma forma. Por isso, "ir à exposição com amigos, quando cada um julga sinceramente, é, assim, uma fonte, às vezes amarga, de surpresa. É difíicil nos resignarmos a esta solidão do gosto, e, até na amizade, a esta prisão estética do eu". Comte-Sponville, A. Mythe d'lcare. Paris, PUF, op. cit.

12 Espinosa, B. Tratado breve, Madrid, Alianza, 1990. p. 124, §. 2.

13 'Uma idéia implícita na noção de 'unicidade' de um indivíduo é a de 'marca positiva' ou 'apoio de identidade', por exemplo, a imagem fotográfica do indivíduo na mente dos outros ou o conhecimento de seu lugar espećífico em determinada rede de parentesco". Goffman, E. Estigma: notas sobre a manipulação da identidade deteriorada. Rio de Janeiro, Guanabara, 1963. p. 66.

14 "Não era esta certamente a Marcela de 1822; mas a beleza de outro tempo valia uma terça parte dos meus sacrificicios? Era o que eu buscava saber interrogando 0 rosto de Marcela. 0 rosto dizia-me que não; ao mesmo tempo os olhos me contavam que, já outrora, como hoje, ardia neles a flama da cobiça. Os meus é que não souberam ver-hha; eram olhos de primeira edição". Machado de Assis, Memórias Póstumas de Brás Cubas, Rio de Janeiro, Instituto Nacional do Livro, 1960. p. 174. 
15 Pascal, B. Pensées. Paris, Garnier, 1951. 688 - 323.

16 "Quando falamos de identidade referimo-nos não a uma espécie de alma ou a uma essência com a qual nascemos, não a um conjunto de disposições internas que permanecem fundamentalmente iguais durante toda a vida, independentemente do meio social onde a pessoa se encontra. Referimo-nos sim a um processo de construção no qual os indivíduos vão se definindo a si mesmos, em estreita interação simbólica com outras pessoas". Larrain J. "El concepto de identidad". In Revista Famecos - Porto Alegre, EDIPUCRS, N. 21, Ago. 2003.

17 Bourdieu, P. "L'illusion biographique". In Actes de la Recherche en Sciences Sociales, n. 62 - 63, 1986, pp. $69-72$.

18 "Portanto, as identidades não são 0 produto de mentes individuais, mas, sim, de relações interpessoais que ganham expressão a partir do recurso social compartilhado da linguagem, nas práticas e nos fluxos comunicativos diários". Moreira Maia, R. "Identidade e discurso: a inclusão do outro". In Fronteiras: estudos midiáticos, v. IV, n. 1, junho/2002. p. $115-133$.

19 Proust, M. Le temps rétrouvé. Paris, Garnier Flammarion, 1986, pp. $289-290$.

20 A identidade não reconhecida, não aceita, produz dissonância entre o que esperamos que pensem de nós e o que efetivamente pensam de nós.

21 Gaulejac, V. L'histoire en héritage. Paris, Desclée de Brouwer, 1999.

22 Bourdieu, P. Ce que parler veut dire. Paris, Fayard, 1982.

23 Taylor, Ch. Sources of the self. Cambridge University Press, 1989.

24 Muxel, A. Individu et mémoire familiale. Paris, Nathan, 1996.

25 Sobre a família como categoria social ler Bourdieu, P. "L'esprit de famille", in Raisons pratiques: sur la théorie de l'action. Paris, Seuil, 1994. Pp. 135 - 144.

26 Thévenot, L. "Le régime de familiarité: Des choses en personne". In Genèse, Paris, PUF, n. 17, 1994. pp. 72101.
27 Jankélévitch, V. L'imprescriptible, Paris, Seuil, 1986, p. 60.

28 Sobre o individualismo na era pós-moralista, ler Lypovetsky, G. Le crépuscule du devoir. Paris, PUF, 1992.

29 Schrag, C. O. The self after postmodernity. New Haven e Londres, Yale University Press, 1997.

30 Como observa Young I., um grupo social distingue-se de um simples coletivo em $f$ unção "do modo pelo qual seus membros se apresentam uns frente aos outros, se autodesignam e produzem 0 auto-entendimento" Intersecting voices. Princeton, Princeton University Press, 1997.

31 Proposta na Lettres ao marquis de Newcastle (23 de novembro de 1646), Classique Garnier, 1973, T. III, pp. $694-695$.

32 Proposta na Erste Philosophie (1922 - 1924) II, Husserliana, T. VIII (La Haye, 1959, pp. 61 - 64). Citada em Husserl, coll. "Philosophes", Paris, PUF, 1964, pp. 116 -118 .

33 Merleau-Ponty, M. Phénoménologie de la perception. Tel Gallimard, 1994, pp. 94 - 95.

34 Habermas também concebe a identidade em formação intersubjetiva nas relações com os outros. Habermas, $\mathrm{J}$. The theory of communication action. Boston, Beacon Press, 1987.

35 "Se os acontecimentos que transcorrem em nós pudessem ser explicados unicamente pela nossa própria natureza, poderíamos, totalizando-os, compreender esta natureza. Se nosso corpo funcionasse em seu nível de atualização ótimo, 0 ordenamento dos seus afetos seria a expressão adequada da sua essência. Neste caso, a alma, idéia do corpo existente em ato, teria explicitamente a idéia da essência deste corpo. Mas não é assim: nosso corpo, na verdade, existe apenas deformado por causas exteriores. Torna-se, portanto, inconhecível. 0 encadeamento desordenado de seus afetos não nos permite reconstituir sua lei interna. Sua estrutura está lá, mas camuflada pelo fluxo de determinações que the chegam do meio". Matheron, A. Individu et communauté chez Spinoza. Paris, Minuit, 1987, p.312.

36 "Se não reconhecemos as cores mais matizadas, mais confusas, mais misturadas de nossa vida, é porque alegria 
e tristeza se mesclam, claro, é porque não cessamos de hesitar, de oscilar, de flutuar entre estes dois afetos". Comte Sponville, A. Petit Traité des Grandes Vertus, Paris, PUF, 1995. (trad. Pequeno tratado das grandes virtudes. São Paulo, Martins Fontes, 2000. p. 273)

37 "Quando encontramos um corpo exterior que não convém com o nosso - isto é, um corpo cujas relações entre suas partes não se compõe com o nosso - tudo se passa como se a potência deste corpo se opusesse à nossa potência, operando uma subtração, uma fixação: dizemos que nossa potência de agir foi diminuída ou impedida e que as paixões correspondentes são de tristeza". Deleuze, $G$. Spinoza: philosophie pratique. Paris, Minuit, 2003. p. 41.

38 Para quem "o ser é o ser percebido".

39 "O desejo não é um afeto entre outros, mas o movimento da potência de agir: esta aumenta ou diminui e forma, então, os afetos de alegria e de tristeza, bem como todos os afetos derivados: a inveja é uma forma de tristeza, 0 amor é uma forma de alegria". Misrahi, R. Spinoza et le spinozisme. Paris, Armand Colin, 1998. p. 44.

40 Polin, R. La création des valeurs. Paris, PUF, 1944, p. 157.

41 Como exemplo de proposta que apresenta a ética na comunicação como uma entre outras e, portanto, implicitamente sustenta a possibilidade de ética sem comunicação, ler Barros Filho, C. (não confundir com 0 autor deste artigo, felizmente afetado por discursos esclarecedores desde a sua primeira edição - 1995) Ética na comunicação. São Paulo, Summus, 2003.

42 Comte-Sponville A. La volonté cynique in Valeur et vérité. Paris, PUF, 1994, p. 29.

43 Bakhtin, M. vai torná-los indissociáveis. Marxismo e filosofia da linguagem. São Paulo, Hucitec, 1987.

44 Chaui, M. Espinosa: uma filosofia da liberdade, São Paulo, Moderna, 1995. p. 67.

45 "Assim, a vida não tem nada de específico e as noções mais ou menos confusas pelas quais de ordinário se a representa não têm nenhum valor explicativo próprio: 0 esforço para perseverar no ser, ao qual ela se reduz, não é uma espontaneidade que se determina sob a razão de fins". Delbos, V. 0 espinosismo. São Paulo, Discurso, 2002. p. 121.

46 Weintraub, K. J. The value of the individual. Chicago, University of the Chicago Press, 1978.

47 Caujolle-Zaslawsky, F. "Sophistique et scepticisme", in Positions de la sophistique, Paris, PUF, 1979. p. 157.

48 Diferentemente da paixão, agimos quando algo acontece em nós ou fora de nós de que somos a causa adequada, isto é, explicável exclusivamente pela nossa natureza. Sobre as conseqüências da separação espinozana entre ação e paixão, ler Alain, Spinoza. Paris, Gallimard, 1996. p. $62-65$.

49 Séverac, P. Éthique-Spinoza. Paris, Ellipses, 1997. p. 24.

50 Sobre a sociabilidade em Espinosa, ver Balibar Etienne, Spinoza et la politique, P.U.F., coll. "Philosophies", Paris, 1985.

51 "Eu e outro somos como dois círculos quase concêntricos, que só se distinguem por um leve e misterioso afastamento. É esta semelhança 0 que talvez nos permita entender a relação com 0 outro...". Merleau-Ponty, M. La prose du monde. Paris, Gallimard, 1989. p. 185.

52 Espinosa, B. Ética, op. cit., IV, prop. XXIX, demonstração.

53 "Não se deve ser nem rústico nem estranho, mas agradável e familiar, porque nenhuma diferença haveria da murta à gibaldeira, se uma não fosse familiar e a outra selvagem. Sabe que são agradáveis os que no trato comum têm os mesmos modos que costumam ter os amigos entre si. Quem é estranho parece em todo lugar estrangeiro, 0 que equivale a dizer forasteiro, enquanto os familiares, aonde quer que possam ir, parecem, pelo contrário, ser conhecidos e amigos de todos". Della Casa, G. Galateo ou dos costumes. São Paulo, Martins Fontes, 1999, p. 22.

54 Nesse sentido, para Young, I. (op. cit. p. 393) a identidade é produto que depende da existência de posições sociais intersectantes.

55 A influência é certa. A explicação mecanicista, tentadora. Mas a participação das classes na lógica interna do campo deve ser avaliada pela ótica da singularidade da trajetória 
de cada agente, de seu habitus.

56 MARY, A. "Le corps, la maison, le marché et les jeux. Paradigmes et métaphores dans le "bricolage" de la notion d'habitus". In Lectures de Pierre Bourdieu, Cahiers du LASA, Caen, Université de Caen, 8-9, 1989. p. 9- 102.

57 "O esforço para perseverar no ser é geral para tudo o que existe, mas se exprime de diversas maneiras em naturezas diferentes. No que concerne 0 homem, 0 conatus que the é próprio é - se considerarmos o espírito, a vontade, não enquanto faculdade de livre arbítrio (excluído por Espinosa) - o esforço para fazer e obter tudo o que aumenta a potência do corpo e evitar tudo 0 que a diminuil'. Cristofolini, P. Spinoza - Chemins de l'éthique. Paris, PUF, 1996. p. 43.

58 Declaração de Geraldo Alckmin, durante o segundo debate para o primeiro turno das eleições para prefeito de São Paulo, em 2000, exibido pela Band.

59 Declaração de Jorge Kajuru no programa Esporte Total da Band (18/07/03).

60 Declaração de um derrotado anônimo em qualquer momento de derrota.

61 Quanto mais uma imagem está junta a um maior número de outras mais freqüentemente é avivada".Espinosa, B. Ética, op. cit. V, prop. 13.

62 Matheron, A. op. cit. p. 67 e Espinosa, B. Ética. op. cit. II, prop. 18.

63 A eventual distância entre uma cultura objetiva e a cultura subjetiva, ou ainda, a consciência da distância possível entre a objetivação e a alienação fazem parte, de há muito, das preocupações das ciências sociais. A idéia de que 0 ator sedimenta apenas uma parte da memória social, no limite dos flagrantes da sua trajetória singular, e que a cultura objetivada se transmite de geração em geração é uma representação que, enunciada de múltiplas maneiras, esta presente em muitas propostas sociológicas. Para um balanço das mesmas ler Héran, F., "La seconde nature de l'habitus. Traditions philosophique et sens commun dans le langage sociologique". In Revue Française de Sociologie, V. XXVIII, N. 3, 1987, pp. $385-416$.

64 As dobras do social se encontram assim incorporadas nos indivíduos sob forma de hábitos. Por vezes, insiste-se, em última instância, no primado da dimensão do "papel social" sobre a identidade, quando se afirma que são os contextos que comandam a cada instante a unificação do ator para as necessidades da ação. Já outros destacam que, em função da situação, o indivíduo se engaja na ação servindo-se de diversos referenciais em repertório que ele disponibiliza. Ver Corcuff, Ph. Le collectif au défi du singulier: en partant de l'habitus, In Lahire, B. (ed.), Le travail sociologique de Pierre Bourdieu, Paris, La Découverte, 1999 e também Acteur pluriel contre habitus? in Politix, N. 48, 1999. pp. 157 - 173. 